\section{Pacific Northwest}

National Laboratory

Operated by Battelle for the

U.S. Department of Energy

\title{
Atmospheric Radioxenon Measurements in North Las Vegas, NV
}

\author{
B. D. Milbrath \\ M. Cooper \\ L. S. Lidey \\ T. W. Bowyer \\ J. C. Hayes \\ J. I. McIntyre \\ Pacific Northwest National Laboratory
L. Karr
D. Shafer
J. Tappen \\ Desert Research Institute
}

July 2006

Prepared for the U.S. Department of Energy under Contract DE-AC05-76RL01830 


\title{
DISCLAIMER
}

This report was prepared as an account of work sponsored by an agency of the United States Government. Neither the United States Government nor any agency thereof, nor Battelle Memorial Institute, nor any of their employees, makes any warranty, express or implied, or assumes any legal liability or responsibility for the accuracy, completeness, or usefulness of any information, apparatus, product, or process disclosed, or represents that its use would not infringe privately owned rights. Reference herein to any specific commercial product, process, or service by trade name, trademark, manufacturer, or otherwise does not necessarily constitute or imply its endorsement, recommendation, or favoring by the United States Government or any agency thereof, or Battelle Memorial Institute. The views and opinions of authors expressed herein do not necessarily state or reflect those of the United States Government or any agency thereof.

\author{
PACIFIC NORTHWEST NATIONAL LABORATORY \\ operated by \\ BATTELLE \\ for the \\ UNITED STATES DEPARTMENT OF ENERGY \\ under Contract DE-AC05-76RL01830
}

Printed in the United States of America
Available to DOE and DOE contractors from the Office of Scientific and Technical Information,
P.O. Box 62, Oak Ridge, TN 37831-0062;
ph: (865) 576-8401
fax: $(865)$ 576-5728
email: reports@adonis.osti.gov

\begin{abstract}
Available to the public from the National Technical Information Service, U.S. Department of Commerce, 5285 Port Royal Rd., Springfield, VA 22161 ph: (800) 553-6847 fax: $(703) 605-6900$ email: orders@ntis.fedworld.gov online ordering: http://www.ntis.gov/ordering.htm
\end{abstract}

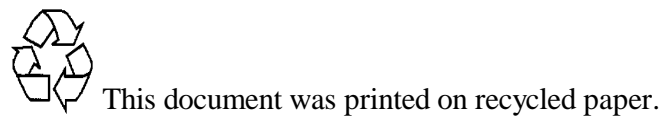




\title{
Atmospheric Radioxenon Measurements in North Las Vegas, NV
}

\author{
B. D. Milbrath \\ M. Cooper \\ L. S. Lidey \\ T. W. Bowyer \\ J. C. Hayes \\ J. I. McIntyre \\ Pacific Northwest National Laboratory \\ L. Karr \\ D. Shafer \\ J. Tappen \\ Desert Research Institute
}

July 2006

Prepared for the U.S. Department of Energy under Contract DE-AC05-76RL01830

Pacific Northwest National Laboratory

Richland, WA 99352 


\section{Summary}

PNNL deployed the ARSA radioxenon measurement system in North Las Vegas for two weeks in February and March 2006 for the purpose of measuring the radioxenon background at a level of sensitivity much higher than previously done in the vicinity of the NTS. The measurements establish what might be expected if future measurements are taken at NTS itself. The measurements are also relevant to test site readiness. A second detector, the PEMS, built and operated by DRI, was deployed in conjunction with the ARSA and contained a PIC, aerosol collection filters, and meteorological sensors. Originally, measurements were also to be performed at Mercury, NV on the NTS, but these were canceled due to initial equipment problems with the ARSA detector.

Some of the radioxenon measurements detected ${ }^{133} \mathrm{Xe}$ at levels up to $3 \mathrm{mBq} / \mathrm{m}^{3}$. This concentration of radioxenon is consistent with the observation of low levels of radioxenon emanating from distance nuclear reactors. Previous measurements in areas of high nuclear reactor concentration have shown similar results, but the western US, in general, does not have many nuclear reactors. Measurements of the wind direction indicate that the air carrying the radioxenon came from south of the detector and not from the NTS. 



\section{Acronyms and Abbreviations}

$\begin{array}{ll}\text { ARSA } & \text { Automated Radioxenon Sampler Analyser } \\ \text { CEMP } & \text { Community Environmental Monitoring Program } \\ \text { CTBT } & \text { Comprehensive Nuclear-Test-Ban Treaty } \\ \text { DRI } & \text { Desert Research Institute } \\ \text { DOE-NV } & \text { DOE-Nevada Operations Office } \\ \text { IMS } & \text { International Monitoring System } \\ \text { MDC } & \text { Minimum Detectable Concentration } \\ \text { NaI(Tl) } & \text { sodium iodide(thallium-doped) } \\ \text { NTS } & \text { Nevada Test Site } \\ \text { PEMS } & \text { Portable Environmental Monitoring Station } \\ \text { PIC } & \text { Pressurized Ion Chamber } \\ \text { PNNL } & \text { Pacific Northwest National Laboratory } \\ \text { TCD } & \text { Thermal Conductivity Detector }\end{array}$





\section{Contents}

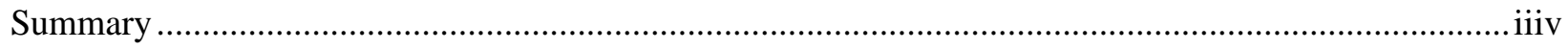

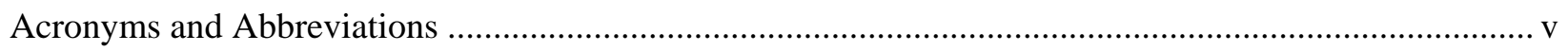

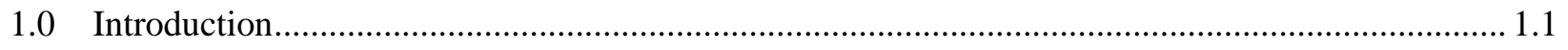

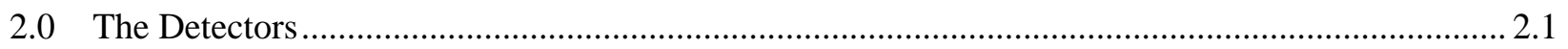

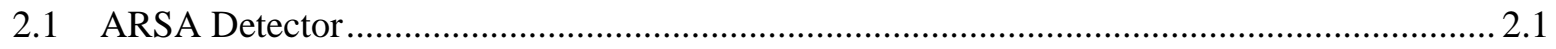

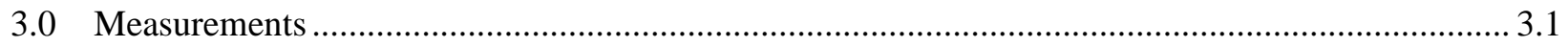

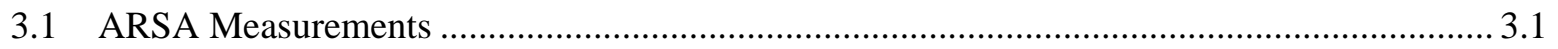

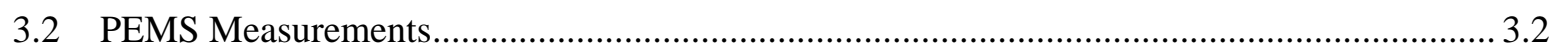

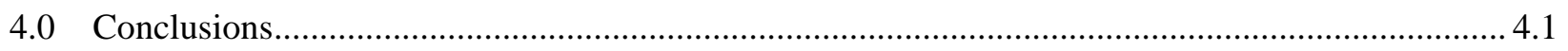

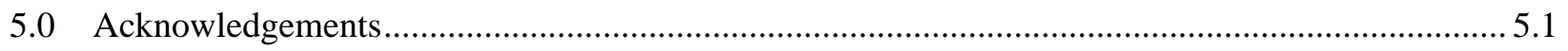

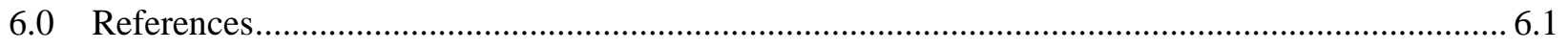

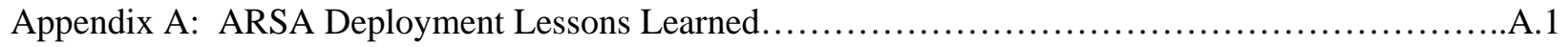

\section{Figures}

Figure 1-1. The PEMS (foreground) and ARSA detectors in front of the Rack Assembly Tower. ......... 1.2

Figure 2-1. The ARSA system with various components labeled. ...................................................... 2.1

Figure 2-2. The ARSA detector in a trailer at DOE-NV ..................................................................... 2.2

Figure 2-3. Electric distribution box used at DOE-NV ................................................................... 2.3

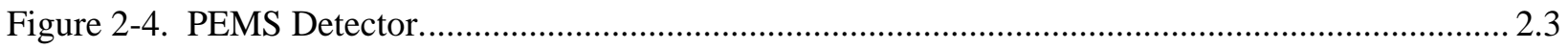

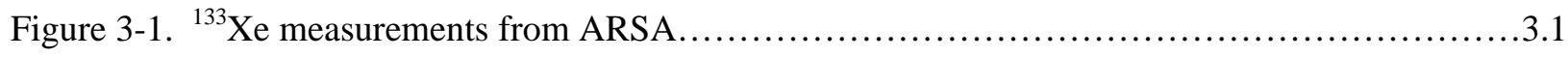

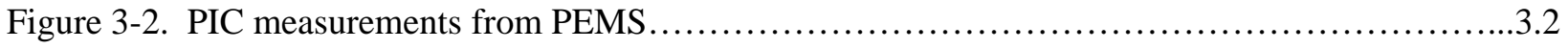

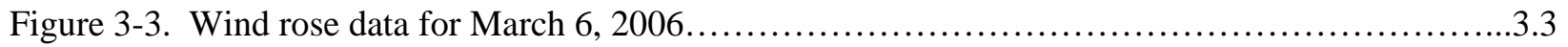




\subsection{Introduction}

In the 1990s, PNNL developed the Automated Radioxenon Sampler/Analyzer (ARSA) as a prototype sampling station for the International Monitoring System (IMS) [Bowyer 2002]. The IMS is a network of stations originally developed to monitor compliance with the Comprehensive Nuclear-Test-Ban Treaty (CTBT). Ultimately, the IMS will have at least 40 radioxenon sampling stations placed around the world [Protocol]. Concurrent with ARSA's development, was the development of similar detectors by a few other countries: France, Russia, and Sweden. The automated nature of the detectors is crucial as several of the planned stations are to be at remote locations. The ARSA and its counterparts are much more sensitive than anything commercially available, with sensitivities as low as $0.1 \mathrm{mBq} / \mathrm{m}^{3}$ [Bowyer 2002].

Radioxenon is in the mass range where large fission yields occur from uranium- or plutonium-based nuclear weapons. In a nuclear explosion, several radioxenon isotopes are produced with half-lives convenient for detection (short enough for high radioactivity, but long enough for detection): ${ }^{135} \mathrm{Xe}(9.14$ hr), ${ }^{133} \mathrm{Xe}(5.25 \mathrm{~d}),{ }^{133 \mathrm{~m}} \mathrm{Xe}(2.19 \mathrm{~d})$, and ${ }^{131 \mathrm{~m}} \mathrm{Xe}$ (11.93 d). As an inert noble gas, xenon doesn't combine chemically with other elements (in ground or atmosphere) and is likely to escape even from an underground explosion. Nuclear reactor operations also release radioxenon, and there are some medical and industrial sources [Bowyer 1998]. ${ }^{133} \mathrm{Xe}$ is detected much more frequently than the other three radioxenon isotopes during normal atmospheric monitoring [Auer].

Radioactive noble gas detection is internationally accepted, can accommodate significant stand-off distances, and is quite sensitive without being overly intrusive (i.e., revealing detailed information relative to weapon design). Given its importance in international monitoring and the fact that such sensitive noble gas measurements have not previously been performed at the Nevada Test Site (NTS), it was decided that measurements should be performed using the ARSA to establish a baseline of comparison to possible future NTS background measurements. DOE-NV was also interested in the measurements for test site readiness purposes. Thus, it was decided to perform a pair of measurements with the ARSA; first near Las Vegas, 65 miles away from NTS, and then at the NTS’s Mercury townsite.

This report details those measurements, performed in February and March 2006 in the trailer parking lot south of the Rack Assembly Tower (bldg. A-14) at DOE-NV in North Las Vegas, NV. (See Figure 11.) Originally, measurements were also planned to occur near the Environmental Services Building (Bldg. 652) in Mercury, NV on the NTS, but equipment problems after transport of the ARSA from PNNL precluded having time to conduct both measurements. In tandem with the ARSA, measurements were also made using the Portable Environmental Monitoring Station (PEMS) constructed and operated by the Desert Research Institute (DRI). The PEMS is modeled after the Community Environmental Monitoring Program (CEMP) stations operated by DRI around the NTS [CEMP]. 


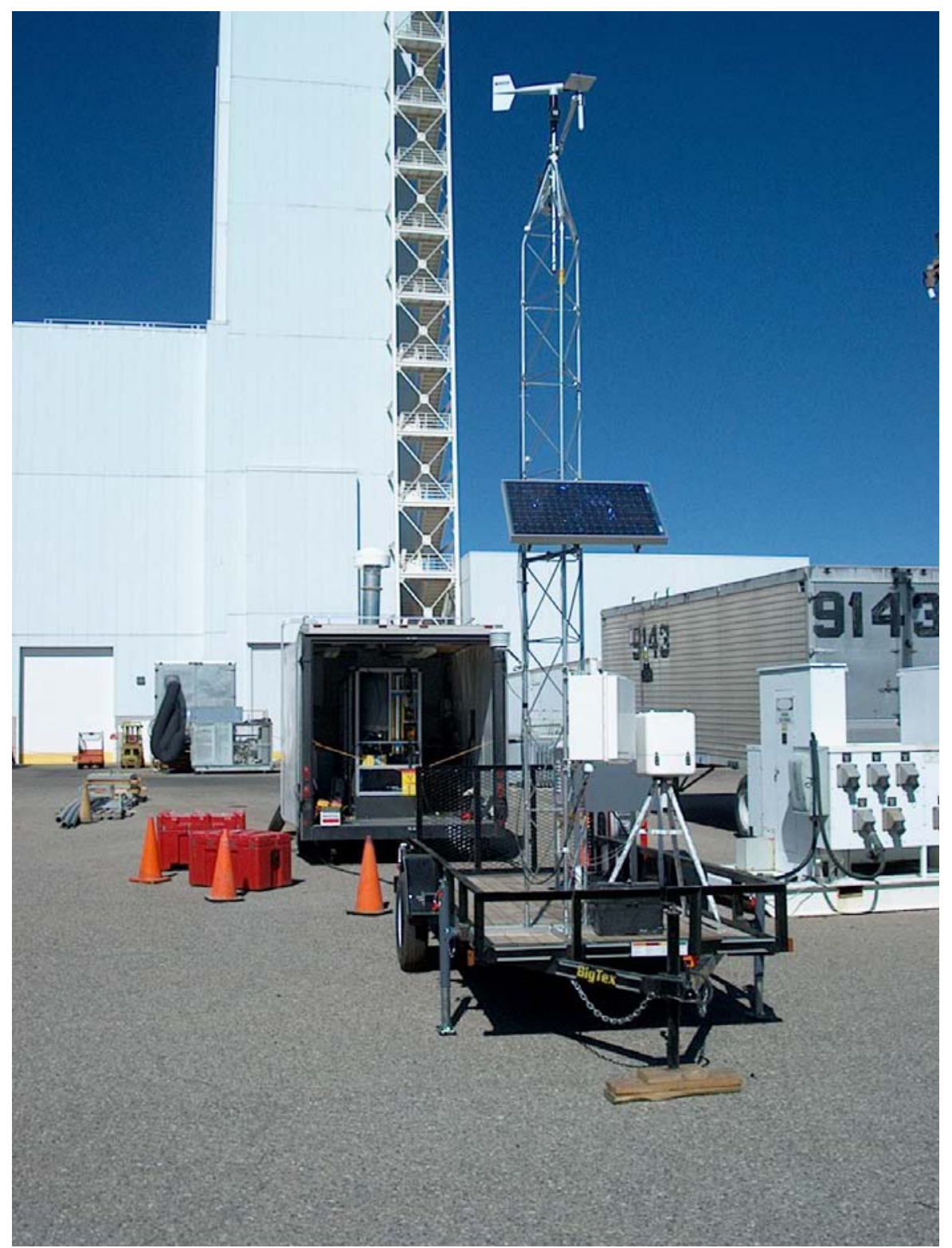

Figure 1-1. The PEMS (foreground) and ARSA detectors in front of the Rack Assembly Tower. 


\subsection{The Detectors}

Two detectors were deployed: the ARSA and the PEMS.

\subsection{ARSA Measurement System}

The ARSA is about the size of two soda machines and weighs approximately 3000 pounds. (See figure 2-1.) It takes in air at the rate of $144 \mathrm{~m}^{3} /$ day (one $48 \mathrm{~m}^{3}$ sample each eight hours) from the outside and separates and concentrates the $87 \mathrm{ppb}$ Xe present. The air is first compressed, filtered, cooled, and moved through dryers to remove the $\mathrm{H}_{2} \mathrm{O}$ and $\mathrm{CO}_{2}$. A series of adsorption charcoal traps are used to remove first the radon, and then the xenon from gases of even lower boiling points. These traps must be regenerated (outgassed using heat) after each sample. Pre-purified nitrogen is used as a carrier gas. Additional traps are used for further removal of contaminant gasses, though some radon still gets through and is the chief source of background [Bowyer 1999]. Radioxenon counting is performed using a betagamma coincidence cell based on $\mathrm{NaI}(\mathrm{Tl})$ and plastic scintillator, which is surrounded by a lead cave to reduce background [McIntyre]. After counting, a thermal conductivity detector (TCD) is used to quantify the amount of Xe in the sample. Archive bottles may be filled for later retrieval and lab analysis.

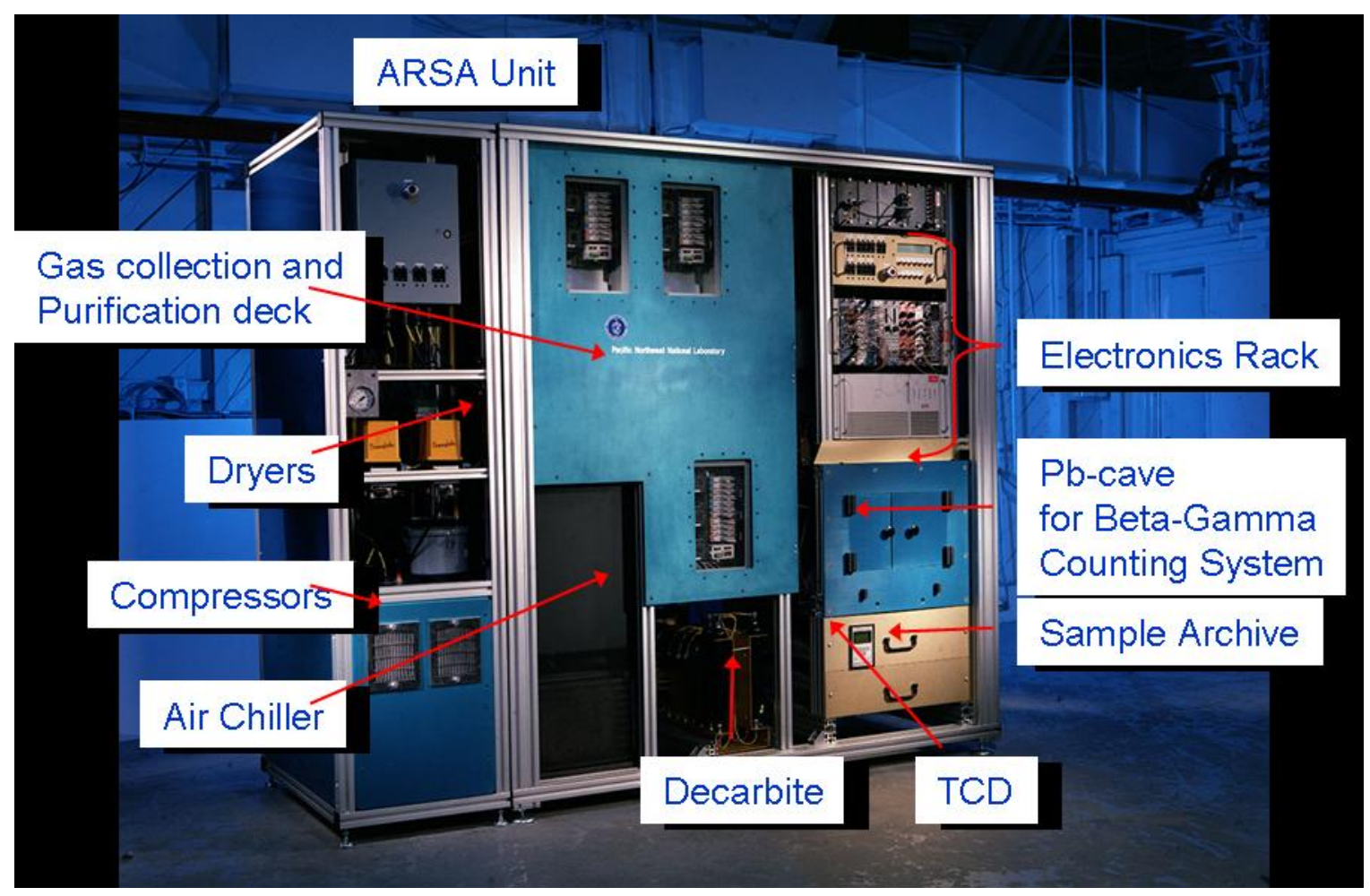

Figure 2-1. The ARSA system with various components labeled. 
In order that ARSA be continuously monitoring the atmosphere, many of the above steps are performed with parallel subsystems. For example, there are four beta-gamma nuclear detector cells. Every 8 hours, a 24-hour count is completed for one sample. Before starting a new 24-hour sample count, an 8-hour "background" count is measured for a given cell for subsequent subtraction. This is necessary, in part, because some residual xenon and radon gas adheres to the cell walls, resulting in a "memory effect" [McIntyre]. When operating properly, the ARSA has a sensitivity of approximately 0.1-0.2 $\mathrm{mBq} / \mathrm{m}^{3}$ for ${ }^{133} \mathrm{Xe}$.

For this deployment, ARSA was transported in a trailer from PNNL to North Las Vegas. In previous ARSA deployments, the detector was dismantled and shipped by container. Transport by road appeared to result in some minor damage to ARSA upon arrival. Problems that were found and corrected during the first week of the deployment included: a broken compressor mount, a broken metal gas line, and a leak in the ARSA gas analysis system. Also, on warm days $\left(>70^{\circ} \mathrm{F}\right)$ the compressor overheated-a problem which was solved by placing fans throughout the trailer and manning the trailer during the heat of the day so that the doors could be left propped open. Additional problems caused the system to shut off twice during the first week. Whenever ARSA shuts off, between 16-24 hours are lost concerning data because the traps must be adequately regenerated before reliable measurements can be performed. A complete "Lessons Learned" is provided in Appendix A for future ARSA deployments.

Figure 2-2 shows the ARSA and its trailer, as deployed in the trailer parking lot south of the Rack Assembly Tower at DOE-NV in North Las Vegas. Figure 2-3 shows the electrical box assembled by Bechtel-Nevada to supply the detectors with power from one of the large electrical distribution panels placed throughout the parking lot. The line voltage at North Las Vegas was approximately 210 volts AC, whereas, it is typically 235 volts AC at PNNL. This voltage change caused some of the equipment to run at measurably different levels (temperatures, flow rates, pressures...) but this did not cause any discernable problem.

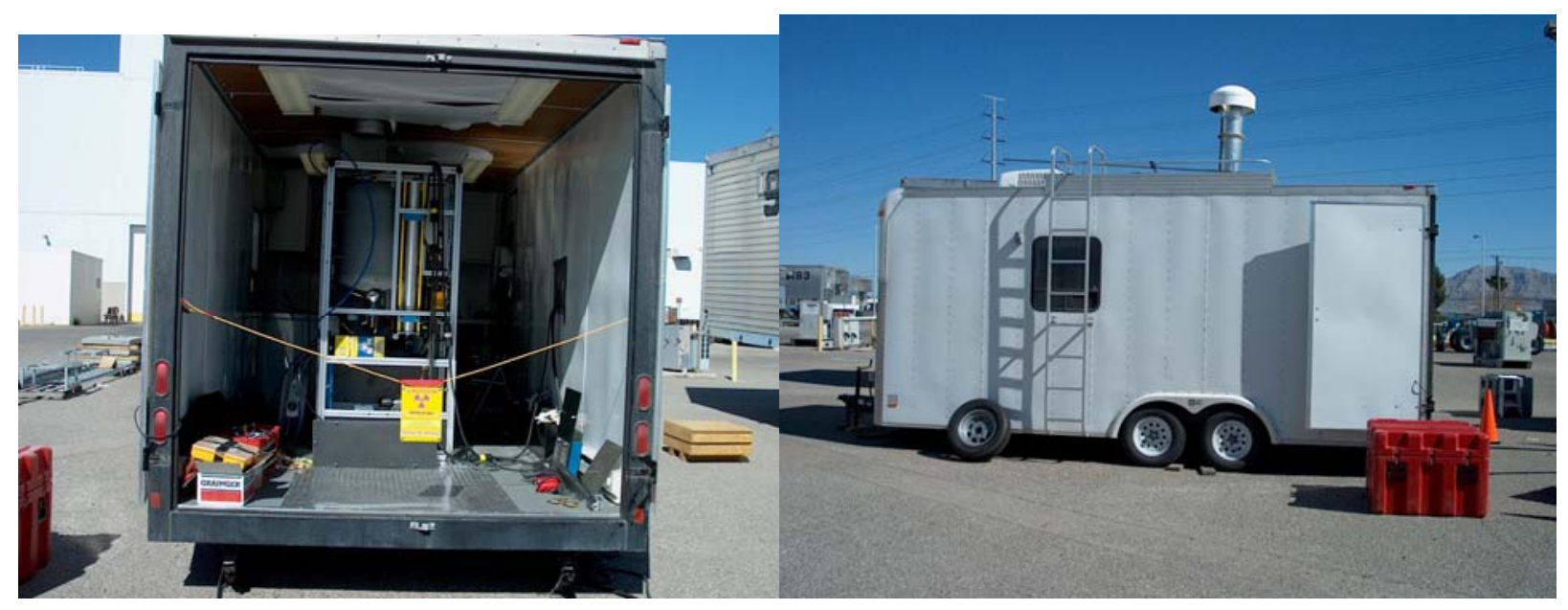

Figure 2-2. The ARSA detector in a trailer at DOE-NV. 


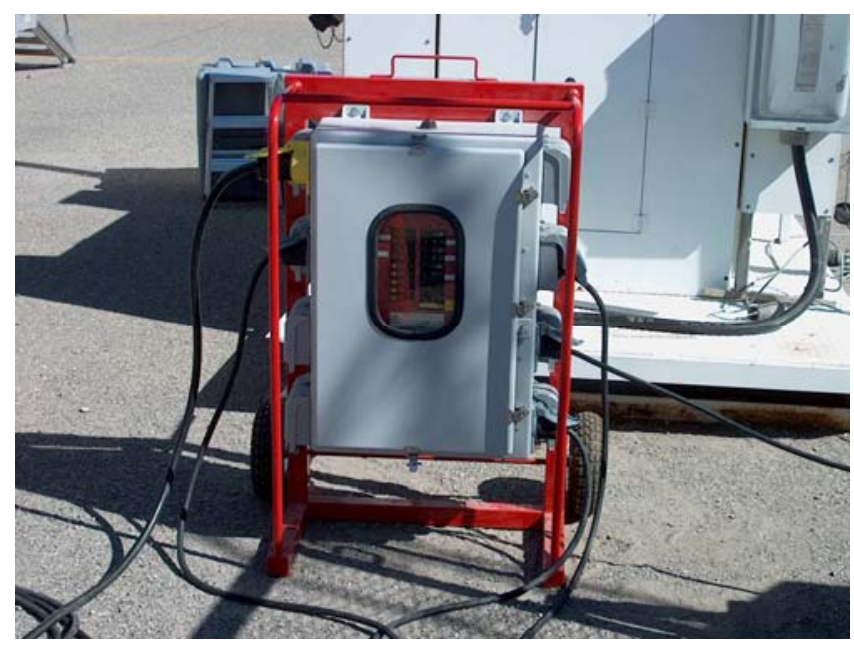

Figure 2-3. Electric distribution box used at DOE-NV.

Figure 2-4 shows the PEMS detector as deployed for this measurement. The weather "tower" (on the left side of the picture) measured wind speed and direction, air temperature, humidity, barometric pressure, and precipitation. To the right in the picture, on a triangular stand, is a Reuter-Stokes Pressurized Ion Chamber (PIC), capable of measuring gamma exposures of 2-800 $\mu \mathrm{R} / \mathrm{hr}$. Rightmost on the PEMS trailer (shaped like a doghouse) is an air particulate sampler. The sampler collects particulate greater than 0.3 microns in size at a flow rate of 2.0 cubic feet per minute. Two samples of approximately one week each were taken, with the filters analyzed for gammas using well-shielded HPGe detectors at PNNL.

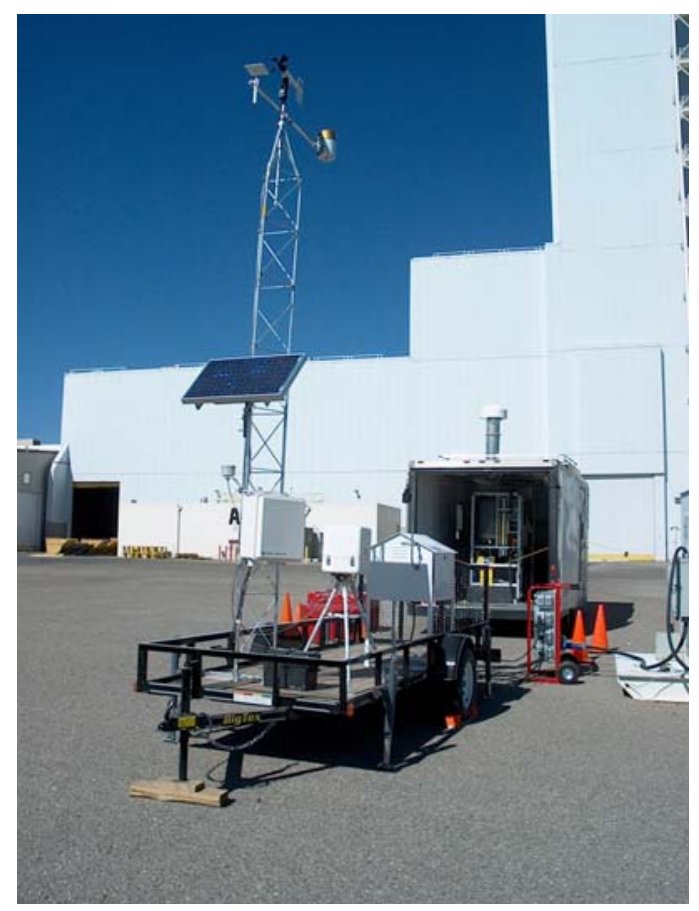

Figure 2-4. PEMS Detector. 


\subsection{Measurements}

The measurements reported are for the period of March 1-7, 2006, when the ARSA was running successfully. The PEMS ran successfully during the entire deployment.

\subsection{ARSA Measurements}

Figure 3-1 shows the detected ${ }^{133}$ Xe concentrations, including statistical errors for the time period. The times shown on the $\mathrm{x}$-axis refer to the midpoint of the sample collection period in local time, which occurred at approximately $5 \mathrm{am}, 1 \mathrm{pm}$, and $9 \mathrm{pm}$ each day. For example, the first measurement occurred at $5 \mathrm{am}$, March $1^{\text {st }}$, and is plotted as 1.21 on the x-axis. There is a gap of four measurements between 9 $\mathrm{pm}$, March $1^{\text {st }}$ and $1 \mathrm{pm}$, March $3^{\text {rd }}$ due to an ARSA shutdown. The pink line shows the minimum detectable concentration (MDC) values, which are typically between 0.1 and $0.2 \mathrm{mBq} / \mathrm{m}^{3}$. The MDC rises at the end due to the memory effect of xenon from the earlier spike remaining in the detection cells. The other three xenon radioisotopes $\left({ }^{135} \mathrm{Xe},{ }^{133 \mathrm{~m}} \mathrm{Xe}\right.$, and $\left.{ }^{131 \mathrm{~m}} \mathrm{Xe}\right)$ are rarely observed and were not observed during this measurement campaign. The average MDC value for ${ }^{135} \mathrm{Xe}$ was $2.1 \mathrm{mBq} / \mathrm{m}^{3}$.

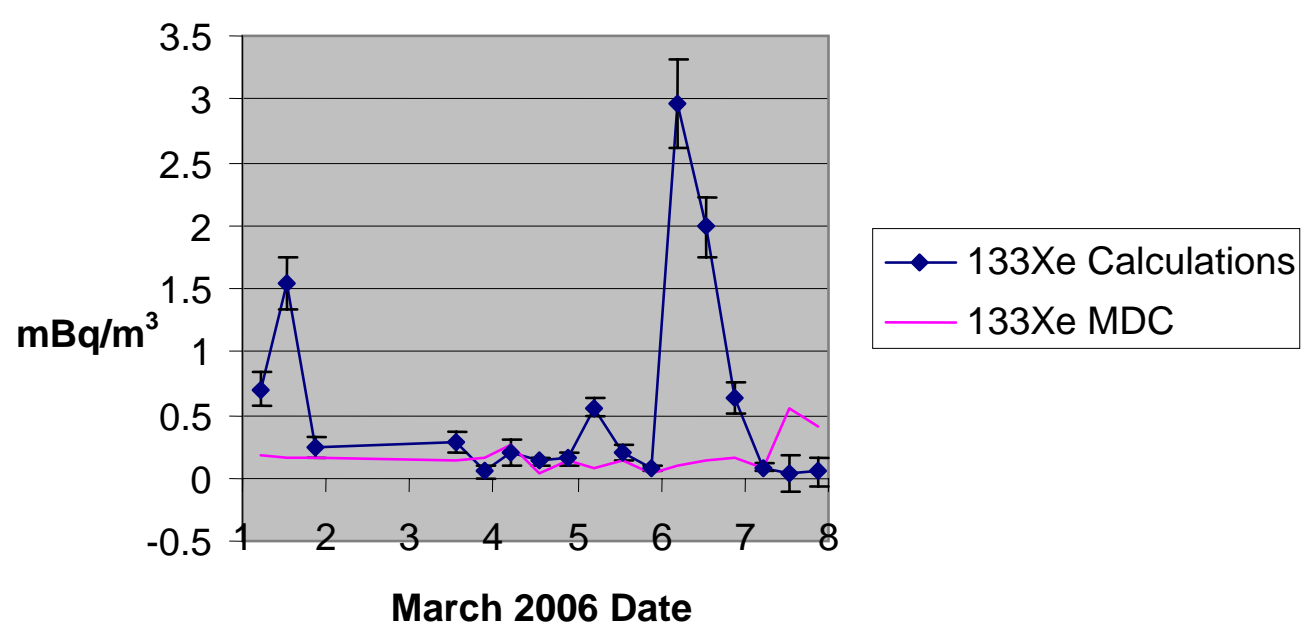

Figure 3-1. ${ }^{133}$ Xe measurements by ARSA, beginning at 00:00 am, March 1, 2006.

${ }^{133}$ Xe was clearly seen a few times at a relatively low level, with the largest spike (almost $3.0 \mathrm{mBq} / \mathrm{m}^{3}$ ) occurring on March $6^{\text {th }}$. Previous, much longer measurements at Freiburg, Germany [Auer] and Allentown, Pennsylvania [Bowyer 1997] frequently measured values of $1-3 \mathrm{mBq} / \mathrm{m}^{3}$. Those two locations were chosen for their proximity to many commercial nuclear reactors. Comparatively, the western United States has much fewer nuclear reactors. Measurements at PNNL, which is only 10 miles from the Columbia Nuclear Generating Station (though usually upwind), only observed radioxenon infrequently[McIntyre]. 
Nuclear reactors release radioxenon as a fission gas, either through cracks in fuel rods, or from neutroninduced fission in uranium on the outside of the fuel rods or in the cooling water [Auer]. Especially large amounts may be released during core refueling [McIntyre], but the observed xenon in this measurement was not large (at Freiburg, ${ }^{133}$ Xe concentrations up to $100 \mathrm{mBq} / \mathrm{m}^{3}$ were observed [Auer]). Although reactors generally have some mechanism in place to trap released radioxenon [Bowyer 1997], it is still the dominant source of released atmospheric radiation for nuclear reactors [Bowyer 1998]. Radioxenon is also used for some medical applications.

\subsection{PEMS Measurements}

Figure 3-2 displays the PIC data from the PEMS detector for the entire time deployment period. The values measured are consistent with those observed at the CEMP station located at DRI in Las Vegas, NV approximately 10 miles away [CEMP Station]. Displayed are the ten-minute average measurements (in units of $\mu \mathrm{R} / \mathrm{hr}$ ) of the gamma activity made by the PIC. The measurements run from 8:30 am, February $22^{\text {nd }}$ through 8:30 am, March $9^{\text {th }}$ (144 measurements per day, as shown on the $\mathrm{x}$-axis). The diurnal variation is quite apparent. The chief source of this radiation is the natural radon background, and any xenon contribution is miniscule.

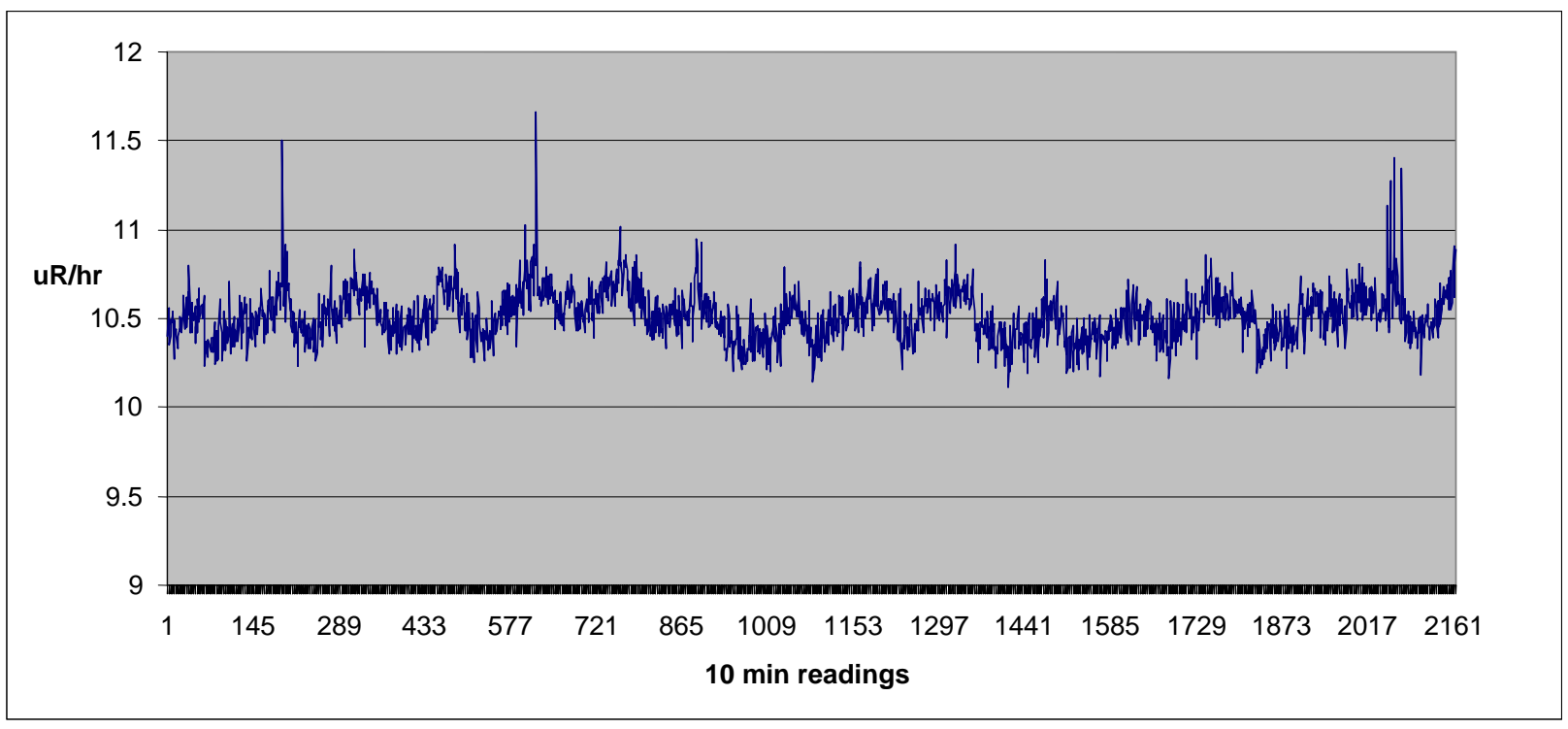

Figure 3-2. 10 minute average PIC measurements by the PEMS, from 8:30 am, February $22^{\text {nd }}$ through 8:30 am, March $9^{\text {th }}, 2006$, in North Las Vegas.

The filters collected by the PEMS were allowed to decay for one week (to reduce the radon contribution) and then measured for approximately two days using a well-shielded HPGe detector. Nothing out of the ordinary was observed. In particular, in the $2-10 \mathrm{pCi} /$ sample level: ${ }^{208} \mathrm{Tl},{ }^{212} \mathrm{~Pb},{ }^{228} \mathrm{Ac}$, and ${ }^{214} \mathrm{~Pb}$ were observed. ${ }^{7} \mathrm{Be}$ and ${ }^{40} \mathrm{~K}$ were measured at approximately $200 \mathrm{pCi} /$ sample. 
The PEMS station also measured meteorological data. Figure 3.3 shows the wind rose from March $6^{\text {th }}$, the day of the largest xenon spike observed. Winds were from the SSW. The NTS is NW of North Las Vegas and thus unlikely to be the source of the radioxenon.

\section{Las Vegas Nevada (DOE-LV)}

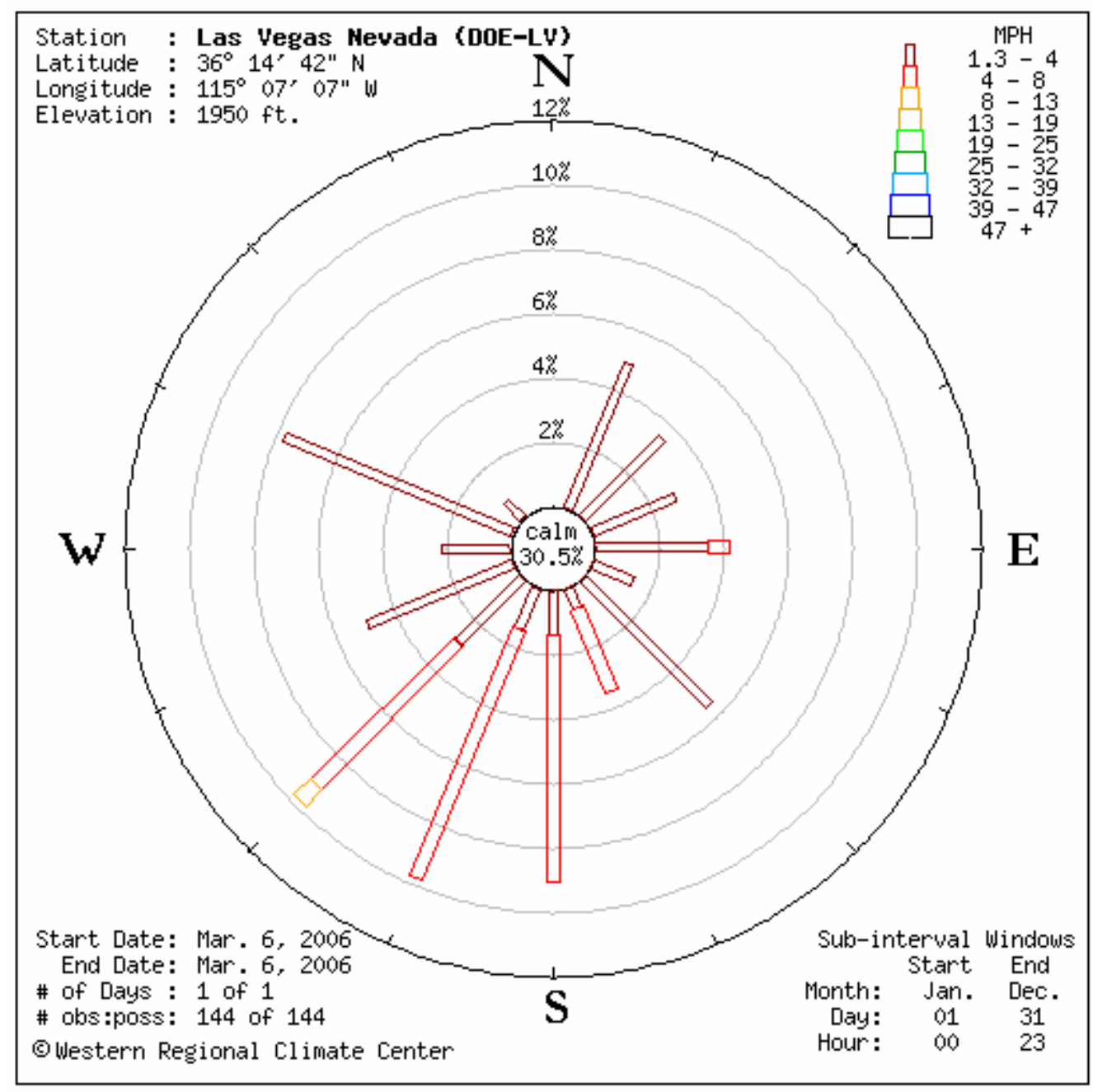

Figure 3-3. Wind Rose for March 6, 2006. 


\subsection{Conclusions}

The ARSA detector was deployed in North Las Vegas for the purpose of measuring the radioxenon background at a level of sensitivity much higher than previously done in the vicinity of the NTS. Such measurements are relevant in case similar measurements are to be performed in the future at NTS itself. A second detector, the PEMS, was deployed in conjunction with the ARSA and contained a PIC and meteorological sensors. Originally, measurements were also to be performed at Mercury, NV on the NTS, but these were canceled due to initial equipment problems with the ARSA detector.

Some ARSA measurements detected ${ }^{133} \mathrm{Xe}$ at levels up to $3 \mathrm{mBq} / \mathrm{m}^{3}$. While this is certainly not a large concentration of Xe, it was somewhat of a surprise. Previous measurements in areas of high nuclear reactor concentrations have shown similar results, but the western US, in general, does not have many nuclear reactors. Wind directions at the time indicated that the radioxenon came from a location south of the detector, and not from the NTS.

The result that the radioxenon background levels in southern NV are generally quite low, but that radioxenon can occasionally be detected is important to future measurements that may occur at the NTS. Follow-up measurements at the NTS and over a longer period (several months, including overlapping wind-direction seasons) would be beneficial. This exercise also provided valuable experience to PNNL concerning the deployment of the ARSA in a more mobile setting than it had in the past, and several improvements would have to be made prior to a subsequent deployment at NTS. 


\subsection{Acknowledgements}

The authors would like to express their appreciation to DOE-NV's Bob Day, Ed Forness, and Daryl Thome for their assistance in site selection and interfacing with the appropriate people at the North Las Vegas and Mercury sites. A special thanks goes to Kent Brooks at the North Las Vegas location for his instrumental documentation work to allow this measurement to occur. Thanks also to Terry Sonnenburg and Robert Peppard who did the same for the Mercury location (which unfortunately didn't take place), including arranging what would have been internet access. PNNL's Tom Heimbigner and Rey Suarez provided computer support, and Elwood Lepel provided measurement analysis of the aerosol filters. DRI’s Scott Campbell and Greg McCurdy supported the PEMS deployment. 


\subsection{References}

Auer M et al. 2004. Intercomparison Experiments of Systems for the Measurement of Xenon Radionuclides in the Atmosphere. App. Rad. and Isotopes. 60, pp. 863-877.

Bowyer TW et al. 2002. Detection and Analysis of Xenon Isotopes for the Comprehensive Nuclear-TestBan Treaty International Monitoring System. J. Env. Rad. 59(2), pp. 139-151.

Bowyer TW et al. 1999. Field Testing of Collection and Measurement of Radioxenon for the Comprehensive Test Ban Treaty. J. Radioanal. and Nuc. Chem. 240(1), pp. 109-122.

Bowyer TW et al. 1998. "Xenon Radionuclides, Atmospheric: Monitoring” in Encyclopedia of Environmental Analysis and Remediation, R. Meyers (Ed.). pp. 5295-5314. John Wiley \& Sons, New York City. ISBN 0-471-11708-0.

Bowyer TW et al. 1997. Ambient 133Xe Levels in the Northeast US. J Env. Rad. 37(2), pp. 143-153.

“CEMP”. http://www.cemp.dri.edu/.

“CEMP Station Summary”. http://www.cemp.dri.edu/cgi-bin/cemp_stations.pl?stn=lasv.

McIntyre JI et al. 2001. Measurement of Ambient Radioxenon Levels Using the Automated Radioxenon Sampler/Analyzer (ARSA). J. Radioanal. and Nuc. Chem. 248(3), pp. 629-635.

Protocol to the Comprehensive Nuclear-Test-Ban Treaty. Part 1, Section C, Paragraph 10, 1996. 


\section{Appendix A: ARSA Deployment Lessons Learned}

There were several factors which prevented this deployment from going as smoothly as hoped, and being as productive as hoped. In particular:

- The ARSA and trailer were both heavier than thought. It was thought that the trailer weighed 3000 pounds while the ARSA weighed 2500 pounds, making a total weight of 5500 pounds, which the trailer was rated as capable of hauling. Instead, the ARSA and trailer weighed over 9000 pounds. This meant that we had to take the lead cave ( 1600 pounds) out of the trailer for shipment, as well as nearly all auxiliary equipment (tools, spare parts, etc.). A heavier-duty trailer would be needed if a similar deployment were to occur in the future.

- ARSA's heat production was not adequately planned for. ARSA's heat output had not been an issue in the air-conditioned laboratory that it resided in prior to deployment. However, once placed in the trailer, which had only a small air conditioner and a few small windows which could be opened, its heat raised the temperature of the trailer substantially above that outside the trailer. We believe this caused the compressor to shut off one afternoon during the deployment when the outside temperature was in the low-70s $\left({ }^{\circ} \mathrm{F}\right)$. Subsequently, we bought several fans - one each to blow on the compressor and the chiller, two to provide airflow through the two windows, and one small one to encourage airflow out the ceiling stack. Also, the trailer was manned in afternoons when the temperature was expected to reach $70^{\circ} \mathrm{F}$ so that the back doors could be opened. These measures would not have worked during a hotter season. If the ARSA were to be deployed again in a trailer, a more-robust cooling system would be needed, along with an exhaust system designed to take heat out of the trailer from the components of ARSA that produce the most heat. For these reasons, deploying ARSA inside of buildings may be preferable.

- $\quad$ ARSA had various compressor problems during the deployment and in the months prior to this deployment. In particular, the vibrations caused by the V-shaped compressors eventually compromised components of the system. A new look at the compressor implementation may be in order.

- ARSA's QNX computer operating system is out-of-date, and our computer personnel recommend that it be upgraded to facilitate program modification work.

- ARSA would benefit from separate electronics for each of its $\mathrm{NaI}(\mathrm{Tl})$ photomultiplier tubes, which currently must use the same gains and offsets, collectively optimized in a tedious process.

- Each time the ARSA is started or restarted, it first heats up the various traps to regenerate them, and then it pauses and waits $0-8 \mathrm{hr}$ to synchronize with one of three certain times of the day before proceeding with sampling. While this makes sense for ARSA's original application of long-term, unattended monitoring, for short deployments under time constraints this is detrimental. Also, there is approximately $1 \mathrm{hr}$ and 50 minutes between when ARSA generates a sample report and when that report is available for ftp'ing and viewing. This slows down diagnosis and trouble-shooting. 
- The effect of 1500 miles of road travel proved to be tougher on ARSA than envisioned, causing several minor problems which, once at a site away from PNNL were harder to diagnose and correct. Several days of lost productivity resulted. Perhaps shipping ARSA in crates, as was done for its Freiburg deployment, is a better option.

- The North Las Vegas site had no ethernet connection available. This would have been desirable for ease of diagnosis of problems. 